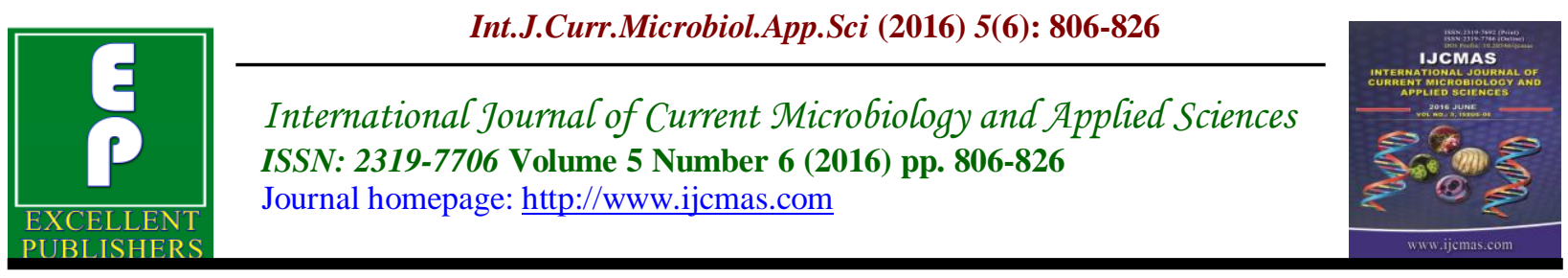

Original Research Article

http://dx.doi.org/10.20546/ijcmas.2016.506.090

\title{
Floristic composition of medicinal plants of Nawada District, Bihar, India
}

\author{
S. M. Ateeque Ahmad', Baidyanath Kumar ${ }^{2 *}$ and Nandji Kumar \\ ${ }^{1}$ Research Scholar, PG. Department of Botany, Magadh University, Bodh Gaya, Bihar, India \\ ${ }^{2}$ Visiting Professor, Department of Biotechnology, Patna Science College, \\ Patna, Patna University, Bihar, India \\ ${ }^{3}$ Professor, PG. Department of Botany Magadh University, Bodh Gaya, Bihar, India \\ *Corresponding author
}

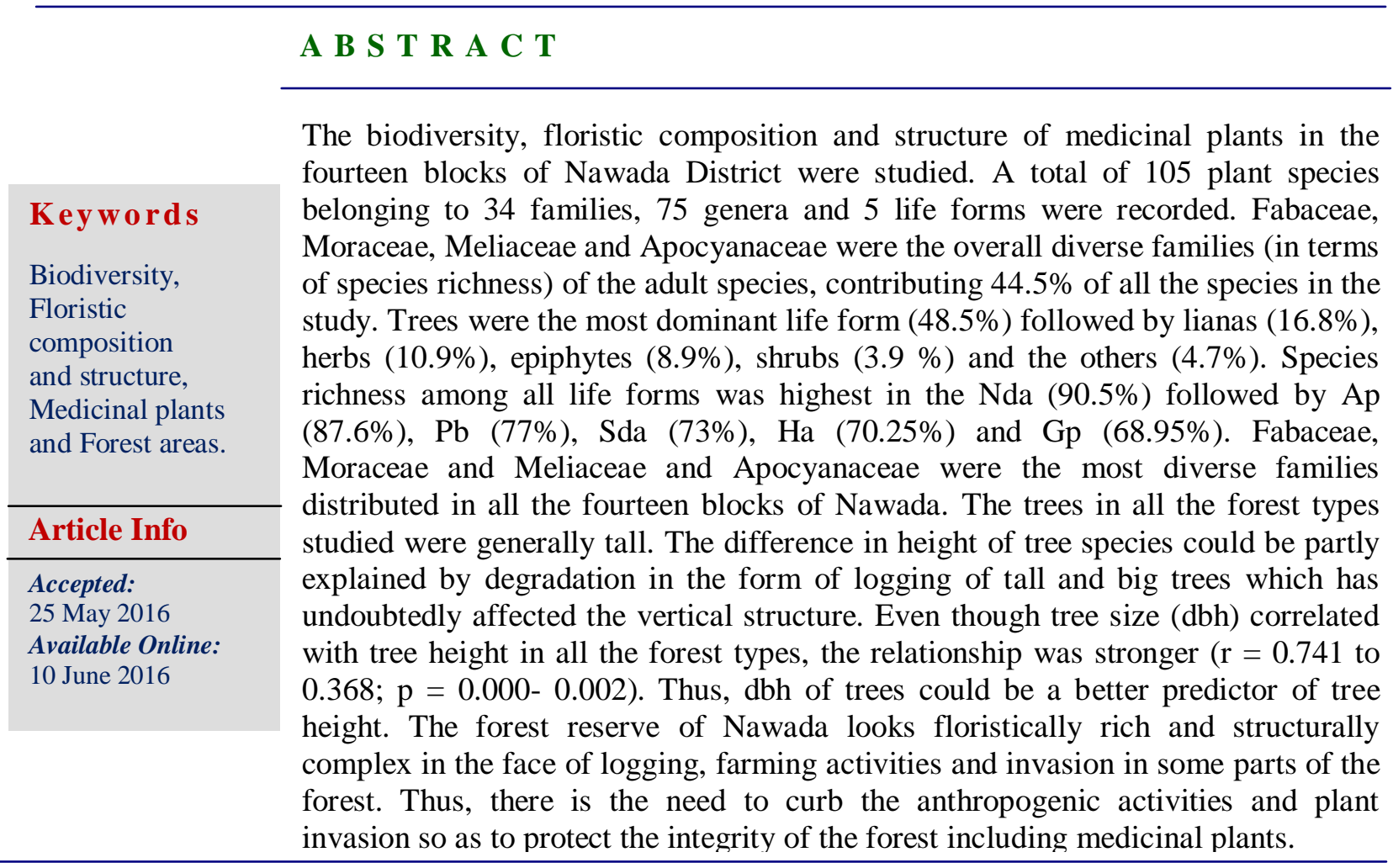

\section{Introduction}

India has a rich herbal heritage which has been described in Ayurveda. It has 16 different agro climatic zones. A large number of plants are available in different bio-geographical zones of India (Gharpure, 2011; Ravi kumar, 2011). According to WHO, 20,000 plant species are used for medicine out of 2, 50,000 all over the world.
Of these eight hundred species are being used commercially. In India, the rural population uses about 8000 herbal plants for medicine. India having a rich traditional knowledge of herbs in the Vedas and ancient days remains marginalized in the fields of research on plants and its medicinal use. The country has a rich herbal heritage and 
about1, 22,600 hectares of land is under cultivation for medicinal plants.

Nawada district is one of the thirty- eight district of Bihar State and Nawada town is the administrative headquarter of this district. It occupies an area of 2,494 square kilometers and is located at $24.88 \mathrm{~N} 85.53 \mathrm{E}$ with an average elevation of 80 meters (262 feets). This district lies on both sides of the river Khuri in $24^{0} 53^{\prime} \mathrm{N}$ and $85^{\circ} 33^{\prime} \mathrm{E}$, and includes fourteen blocks. The climatic conditions of Nawada are somewhat dry and healthy. The winter, summer and rainy seasons are well marked. The overall rainfall is $1142.3 \mathrm{~mm}$ with maximum i.e. around $92 \%$ of rainfall being received during monsoon months.

Modern medicines use many ingredients which have side effect on human organs. This has opened up new vistas of research in herbal medicines. Herbal medicines have no side effect in comparison to the synthetic drugs (Cragg, et al.,1996: Haslam, 2003). Important drugs have been analyzed from plants of Indian origin (Stermitz, et al., 1999; Osborn et al., 2000). Curcuma longa (turmeric), Carica papaya (Papaya) Acacea catechu, Mentha species, Nicotiana tabacum are some of the important plants grown by the farmers of this area. Farmers of this area have adopted the cultivation of Mentha species, Amla, Neem, Gurmae, Sarpgandha etc. These plants have great use in traditional therapy by Ayurveda as well as modern medicine.

The fertile land of Nawada has the potential to grow many herbs of therapeutic use. People of this area utilize "Tilkor Patta" for eating. The Tilkor (Momoradica monadelpha) stimulates insulin secretion from pancreas and therefore it is a used as a herbal product for treatment of diabetes. Not only this, one more species Gurich is found in this region which is also an effective medicine for diabetes. Amla, Jamun, Aloe vera and Gugal are also found in plenty in this area. These herbs have got extensive use in modern medicine.

The plants of medicinal importance are mostly wild whose cultivation is an essential requirement. In Nawada ignorance and lack of preservation knowledge has resulted in the extinction of many plants of medicinal importance.

With the development of synthetic drugs, plant products lost their significance. In the last few decades, however, there has been more interest in drugs obtained from vegetable sources than at any time in historic because of the success with the antibiotics, and other lant drugs such as Rauwolfia (for the treatment of mental disorder), Podophyllum (a cathartic, as well as for curing cancerous tumors in mice), Aloe (a cathartic, as well as for the treatment of atomic radiation burn, Veratrum (hypertensive agent), (Peyote) (psychoactive drug) and sundry others. Sapogenins obtained from many members of Dioscoreaceae and agavaceae, can be converted into cortisone, into male hormone (testosterone) and female hormones (estrogens and progesterone).Sapogenins have many potential uses in the treatment of rheumatoid arthritis and the female hormones are used in contraceptive pills.

The study of drugs and drug plants has developed into modern pharmacognosy which deals with the knowledge of history, botany, preservation and commerce of crude drugs. Nature has provided a rich storehouse of herbal remedies to cure all mankind's ills.

The information on drugs and drug plants whose efficacy in medicine has been established is available in various authentic 
books known as 'Pharmacopoeia' and the drugs included therein are described as 'official'. The most important of these pharmacopoeia are the United States Pharmacopoeia, British Pharmaceutical Codex, Indian Pharmaceutical Codex and National Formulary.

The medicinal value of drugs is due to the presence of certain substances such as alkaloids, glycosides, resins, volatile oils, gums, tannins, etc. Some of these are powerful poisons if administered indiscriminately, while others are dangerously habit- forming. Even the most dangerous drugs can be of value to human beings, if judiciously employed. The danger of self medication is serious and extensive. People who believe themselves ill or simply off- colour physically or mentally, often use wonder- working drugs (happy pills) to relieve themselves from the tensions of modern living. These tranquilizers have proved so effective that their use has increased amazingly and has now outstripped all other drugs with the exception of the antibiotics.

The active principles of plant drugs are commonly more concentrated in storage organs. Roots, seeds, bark and leaves are much represented in the Materia Medica, flowers are less commonly used, while woods and woody parts of herbaceous stems are usually relatively inert.

Floristic composition and studies of medicinal plants are essential in view of their value in understanding the extent of plant biodiversity [World observation Monitoring Centre (WCMC), 1992]. Knowledge of floristic composition is also useful in identifying important elements of plant diversity, protecting threatened and economic species, and monitoring the state of reserves, among others (Tilman, 1988;
Ssegawa and Nkuutu, 2006). Thus, the study of floristic composition and structure becomes more imperative in the face of the ever increasing threat to ecosystem. Studies have shown that composition and structure of plants are influenced by a number of factors (Klinge et al., 1995; Haugaasen et al., 2003). Prominent among these factors are disturbances which are thought to be key aspects, and the cause of local species variation within an ecosystem based on their intensity, scale and frequency (Hill and Curran, 2003; Laidlaw et al., 2007). Disturbances can alter the successional pattern and subsequent composition, diversity, and structure of the plant (Doyle, 1981; Busing, 1995). Logging which has immediate and direct effects on composition and structure (Parthasarathy, 2001) also creates canopy openings which may cause regeneration problems, especially in exposed conditions where soils dry out rapidly and nutrient loss through run-off becomes common. Canopy openings readily support the growth of invasive weeds and other herbaceous plants which usually interfere with regeneration and impede recovery of trees and shrubs (Epp, 1987; Hawthorne, 1993 and 1994; Madoffe et al., 2006). Invasive weeds threaten biodiversity by displacing native species and disrupting community structure (Parker et al., 1999; Richardson et al., 2000; Sala et al., 2000; Stein et al., 2000). Soil water availability is also considered a key factor for the regeneration, survival and growth of seedling communities (Lieberman and Lieberman, 1984; Ceccon et al., 2002). Light conditions influence regeneration pathways strongly (Haugaasen et al., 2003) and ultimately affect the composition and structure of flora of an ecosystem. It has been reported that light limitation alone may prevent seedling survival regardless of other resource levels (Tilman, 1982). Flooding as a limiting factor influences seedling and 
sapling species distribution, and establishment (Klinge et al., 1995; Wittmann and Junk, 2003), probably as a result of physiological stress from highly anoxic conditions, as well as physical flood disturbance (Haugaasen and Peres, 2006). Magadh zone of Bihar is generally believed to be floristically rich, containing many tropical timber species and medicinal plants as well. Carefully compiled and up-to date information on these plant resources is, however, lacking except some fragmentary report (Jyoti and Baidyanath, 2015). Therefore, an attempt has been made to study the floristic composition of medicinal plants of Nawada District (Bihar).

\section{Methodology}

The study was carried out in the fourteen blocks covering almost all the areas of Nawada District (Bihar).These include:

Nawada (Nda), Akbarpur (Ap), Warisaliganj (Wg), Pakribarawan (Pb), Sirdala (Sda), Rajauli (Rjl), Roh (Rh), Kawakol (Kal), Hisua (Ha), Nardiganj (Ndg), Narhat (Nht), Gobindpur (GP), Meskaur (Mkr) and Kashichak (Kac).

The medicinal plants were collected from May 2015 to April 2016 and identified and their dbh (diameter at breast height) measured with a diameter tape. The height of all plants was determined with clinometers. In each quadrate all trees (dbh $\geq 10 \mathrm{~cm}$ ) were examined for the presence of climbers (lianas with $\mathrm{dbh} \geq 2 \mathrm{~cm}$ and vines). Trees were also surveyed for epiphytes according to the method described by AddoFordjour et al. (in press). Trees ( $\mathrm{dbh} \geq 10$ $\mathrm{cm})$ were classified into four groups based on their height; understorey $(<20 \mathrm{~m})$, lowe canopy (20-30 m), upper canopy (30-40 m) and emergent (> $40 \mathrm{~m})$ species. The percentage canopy cover of each plot was determined by a spherical densitometer. At each plot four readings from the four cardinal directions were taken at four different points. The average of all readings for plots in each block (14 readings) was calculated and used as the percentage canopy cover of that forest type (Anning et al., 2008). The diameter of lianas was determined at $1.3 \mathrm{~m}$ from the rooting base (Addo-Fordjour et al., 2009). Each quadrate of $25 \mathrm{~m}$ x $25 \mathrm{~m}$ was subdivided into twentyfive $5 \mathrm{~m}$ x $5 \mathrm{~m}$ small quadrates and fifteen of these (accounting for $60 \%$ of the plot area) were randomly sampled for herbs and regeneration of the tree species. All herbs with $(\leq 2 \mathrm{~m}$ high with $\mathrm{dbh}<10 \mathrm{~cm})$ were identified and counted. Identification was performed by a plant taxonomist aided by manuals and Floras (Hawthorne, 1990; Arbon- nier, 2004; Poorter et al., 2004; Hawthorne and Jongkind, 2006). Identification of the species was confirmed at the KNUST, Kumasi and the Forestry Commission, Kumasi herbaria.

\section{Data Analyses}

Differences in plant densities between the forest types were tested using one-way ANOVA. The relationship between tree size (dbh) and height in the forest blocks was determined by Pearson correlation analysis. These analyses were performed using Minitab 15 software at a significance level of $5 \%$. The diversity of plant species in the forest types was quantified using the Shannon-Wiener species diversity index (Gimaret-Carpentier et al., 1998; Blanc et al., 2000; Parthasarathy, 2001). The Jaccard's index of similarity (I) was calculated for each pair wise plot comparison (Blanc et al., 2000) and this was used to generate a dendrogram showing floristic similarities. The index is given by; 
$I=\frac{C}{\mathrm{Ux}+\mathrm{Uy}+\mathrm{C}}$ x 100

Where,

$\mathrm{C}=$ number of species common to both plot $\mathrm{X}$ and $\mathrm{Y}$

$\mathrm{Ux}=$ number of species found only in plot $\mathrm{X}$ $\mathrm{Uy}=$ number of species found only in plot $\mathrm{y}$.

Epiphytes were excluded from all the above mentioned analyses since their densities could not be determined. Importance value index of the species was calculated as the sum of the species relative density, relative frequency and relative dominance (Kiruki and Njung'e, 2007; Addo-Fordjour et al., 2008).

Besides these areas, some indigenous plants of Nawada used as medicine are also identified, and their medicinal values have been summarized.

\section{Results and Discussion}

Important medicinal plants in Nawada collected in rural areas of fourteen blocks, their habit and the families they belong have been presented in Table-1

In Magadh area of Bihar, the major plants used in indigenous system of medicines have been presented in Table- 2

Family dominance of medicinal plant species in the Nawada District has been presented in Table-3

A total of 105 adult plant species were identified in the fourteen blocks of Nawada. These belonged to 34 families, 75 genera and 5 life forms (Table 1; Figure1 \& 2). Fabaceae, Moraceae, Meliaceae and
Apocyanaceae were the overall diverse families (in terms of species richness) of the adult species, contributing $44.5 \%$ of all the species in the study (Figure 2). Trees were the most dominant life form $(48.5 \%)$ followed by lianas (16.8\%), herbs (10.9\%), epiphytes $(8.9 \%)$, shrubs $(3.9 \%)$ and the others $(4.7 \%)$.

Generally, species richness among all life forms was highest in the $\mathrm{Nda}(90.5 \%)$ followed by the Ap (87.6\%), $\mathrm{Pb}(77 \%)$, Sda (73\%), Ha $(70.25 \%)$ and $\mathrm{Gp}(68.95 \%)$. Fabaceae, Moraceae and Meliaceae and Meliaceae were the most diverse families distributed in all the fourteenblocks of Nawada. The most important families in the Nawada were Fabaceae, Moraceae, Meliaceae and Apocyanaceae (Figure 2). In forest areas of $\mathrm{Wg}$, Rjl, Ha,Ndg, Nht, Mkr and Kac, the medicinal plant species were in the range of 48 to $59.8 \%$. In the forest area of other blocks the incidence of medicinal plant species were low in the range of $29.97 \%$ to $40.30 \%$ (Table- 4 ). C. odorata was the most dominant species of herb in terms of number of individuals accounting for $69 \%$ of individual herbs in the $\mathrm{Nda}$ and $45 \%$ of all the herbs in the forest areas of fourteen blocks.

There were a total of 4167 individuals of woody species (excluding epiphytes) identified in the forest areas of fourteen blocks. Trees were more abundant (2916 individuals/ha) followed by lianas (1603 individuals/ha) and shrubs (248 individuals/ha) (Table - 5). Tree density was greatest in the Kac (290/ha) followed by Gp (287/ha), Mkr (285/ha),Ha (280/ha), Sda (250/ha), Rh (215/ha) and Rjl (214/hac). Density of Liana was maximum in $\mathrm{Pb}(126 /$ ha) followed by Sda (124/ha), Nda (121/ha), and $\mathrm{Wg}$ and Nht (108/ha each). Other areas have low density of Liana. Similarly density of shrubs was maximum in 
$\mathrm{Ab}(19 / \mathrm{ha})$ followed by Kal and $\operatorname{Kac}(17 / \mathrm{ha})$, Rjl (18/ha), Rh (16/ha) and Sda (15/ha). Others have low density of shrubs. ShannonWiener index was greater in the Ap $\left(H^{\prime}=\right.$ 3.80) compared to $\mathrm{Mkr}\left(H^{\prime}=3.70\right)$ and $\mathrm{Rjl}$, $\mathrm{Gp}, \mathrm{Pb}$ and $\mathrm{Kal}\left(H^{\prime}=23.50\right.$ to 3.60). Others have $\mathrm{H}^{\prime}$ value of less than 3.0 (Table 5). Density of plant species differed significantly between the forest types $(\mathrm{F}=8.96: \mathrm{df}=2 ; \mathrm{p}=0.000)$. In all, $C$. mildbraedii was by far the most abundant species accounting for an average $10 \%$ of stems in all the habitats whereas $T$. scleroxylon was the most dominant species in terms of basal area representing $25 \%$ on the average (Table- 5). The overall dominant species in terms of the species importance value (average) were $T$. scleroxylon (28.2) and $C$. mildbraedii (23.7). The commonest species were $C$. mildbraedii and Alafia barteri with the average occurrence of 6.8 and $5.2 \%$ respecttively. On forest type basis C. mildbraedii, C. zenkeri, L. welwitschii, _ansiona altissima, N. papaverifera and $T$. scleroxylon were the dominant species in all the forest areas of eighteen blocks (Table 3). B. papyrifera, C. mildbraedii, $N$. papaverifera, $P$. africanum and $S$. oblonga were the donant species in terms of basal area representing $25 \%$ on the average (Table 3 ). The overall dominant species in terms of the species importance value (average) were T. scleroxylon (28.2) and C. mildbraedii (23.7). The commonest species were $C$. mildbraedii and _lafia barteri with the average occurrence of 6.8 and $5.2 \%$ respecttively.

On forest type basis $C$. mildbraedii, $C$. zenkeri, L. welwitschii,_ansiona altissima, $N$. papaverifera and $T$. scleroxylon were the dominant species in the in all the areas selected for present investigation (Table 3). B. papyrifera, $C$. mildbraedii, $N$. papaverifera, $P$. africanum, $S$. oblonga and $T$. scleroxylon were the species that dominated the woody flora. In terms of size, majority of the trees were of the lower diameter class $(10-30 \mathrm{~cm})$ (Table-5). The number of individual trees in the categories decreased with increasing size of the trees. Larger diameter trees (90- 110 and > 110 $\mathrm{cm})$ were not found in any areas selected for present investigation. Mean basal area recorded was in the range of $32.6 \pm 0.8(\mathrm{Wg})$ to $64.7 \pm 2.6 \mathrm{~m}^{2} / \mathrm{ha}(\mathrm{Mkr})$ (Table 5$)$. In the same way, mean canopy cover and height were higher in the Rjl $(81.3 \pm 4.3)$ followed by $\mathrm{Gp}(80.5 \pm 3.4), \quad \mathrm{Rh} \quad(78.5 \pm 3.0)$, Kal (76.6 \pm 3.5 , Kac $(76.2 \pm 1.6)$, На $(72.5 \pm 1.5)$ and Nht $(68.5 \pm 2.8)$. The canopy cover of other forest areas ranged between $35.5 \pm 0.8$ and $64.7 \pm 2.6$. In the present investigation it was found that there was a significant positive relationship between tree size and height in all the forest types selected for present studies $(\mathrm{r} 2=0.812 ; \mathrm{p}=0.000, \mathrm{r} 2=$ $0.741 ; \mathrm{p}=0.000$ and $\mathrm{r} 2=0.362 ; \mathrm{p}=0.002)$.

Studies on biodiversity, floristic composition and structure in the forests of fourteen blocks of Nawada are instrumental in the sustainability of forests since they play a major role in the conservation of medicinal plant species, and the management of forest ecosystems as a whole (Tilman, 1988; Ssegawa and Nkuutu, 2006). That notwithstanding, only a few studies (Hall and Swaine, 1981; Vordzogbe et al., 2005; Anning et al., 2008) in this regard have been conducted in forest areas. For this reason, the results of this study cannot be compared with a wide range of other similar studies in different blocks of Nawada. On the whole, floristic composition of the forest regions of Nawada was found to be lower than many other tropical areas. For instance, Vordzogbe et al. (2005) reported of much higher species richness (80 species/ha) in a moist semi-deciduous forest in Ghana. Even at a higher diameter cut-off point of $\geq 30$ cm, Parthasarathy (2001) recorded 125 
species in a tropical wet evergreen forest in Sengaltheri of the Western Ghats in India. On the other hand, Anning et al. (2008) recorded a much lower species richness (37 species/ha) in another disturbed semideciduous forest located in Ghana. On the basis of only trees $(\mathrm{dbh} \geq 10 \mathrm{~cm})$ the number of species recorded in this study (28 species/ha) was relatively lower in comparison with similar studies in other tropical forests. For example, Campbell et al. (1986) and Riswan (1987) recorded 189 species/ha and 160 species/ha in Brazilian Amazon and Lempake Indonesia respectively. The cutting of mature trees for timber, farming, collection of fuel wood and other non-timber forest products, and their attendant invasion of some parts of the forest might have had effects on the species composition of the reserve (Terborgh, 1992; Odoom, 2005; Opoku, 2006). Trees constituted the predominant life form in all the forest types reminiscent of other studies (Vordzogbe et al., 2005; Anning et al., 2008). Although shrubs and herbs were generally less prominent in all the forest types, the diversity of herbs was greater in all the areas of fourteen blocks of Nawada. This might be an indicator of greater anthropogenic disturbances in the forest areas of Nawada (Mishra et al., 2008). The comparatively high proportion of Ficus spp. in the epiphytic flora is good for the health of the forest reserve since a lot of Ficus spp. are keystone species in many tropical forests (Lambert and Marshall, 1991). The dominance of $C$. mildbraedii and $T$. scleroxylon in the flora of the forest areas is considered as a major characteristic of semideciduous forests (Taylor, 1960; Hall and Swaine, 1981; Vordzogbe et al., 2005). Furthermore, the dominance of Fabaceae, Moraceae and Meliaceae and Apocyanaceae in some semi-deciduous forests has been reported (Vordzogbe et al., 2005; Anning et al., 2008). Thus, the semi-deciduousness of the forest reserve in Nawada as well as the dominance of these species ( $C$. mildbraedii and T. scleroxylon) (Hall and Swaine, 1981) has been maintained for more than two decades. The presence of some species such as $A$. barteri, $B$. bespubescens, $C$. mildbraedii and $G$. simplicifolia in all the fourteen blocks may indicate their wider range of ecological adaptation (Senbeta et al., 2005; Addo-Fordjour et al., 2008). Floristic composition did not vary much between the various forest types of Nwadathan in the other forest types which continue to be disturbed by human activities. This is buttressed by the density of plant species which was also significantly greater $(p=0.000)$ in the Nda compared to the other blocks. Logging and farming activities in all the eighteen blocks have affected plant diversity through the removal of plant species, creation of gaps, and consequently a reduction in the canopy cover of these forests. Both canopy gaps and farming activities Nawada have favoured the growth of invasive species among the native species, with $C$. odorata and $B$. papyrifera which have been identified as notorious invasive weeds being common phenomena. Though invasive species have been found to exert severe negative consequences on biodiversity, displacing native species and disrupting community structure (Ambika, 1996; Parker et al., 1999; Richardson et al., 2000; Sala et al., 2000; Stein et al., 2000; Madoffe et al., 2006). This could be attributed to the early stage of invasion in the Nawada, indicating that invasion is yet to have it full impact on the flora of the area. Therefore, there is still an opportunity for management intervention to control $B$. papyrifera and $C$. odorata so as to protect the biodiversity of the forest. Compared with other tropical forests, the forest areas ofNawada vertically presented a higher structural complexity 
The trees in all the forest types studied were generally tall. The difference in height of tree species could be partly explained by degradation in the form of logging of tall and big trees which has undoubtedly affected the vertical structure. Even though tree size (dbh) correlated with tree height in all the forest types, the relationship was stronger $(r=0.741$ to $0.368 ; p=0.000$ 0.002 ). Thus, dbh of trees could be a better predictor of tree height. Age of trees has been found to influence the relationship between tree height and dbh with younger forests showing a stronger relationship than matured forests (Ryan and Yoder, 1997). Thus, the cutting down of matured trees was at least partly responsible for the better correlation between these parameters compared to the other forest types. Generally, tree density in relation to vertical structure of the forest, decreased with increasing height of canopy layers. The cutting down of large trees could explain the relatively lower mean basal area of woody species in these forest types.

The greatest diversity of saplings $\left(\mathrm{H}^{\prime}\right)$ in the DB could be attributed to higher sunlight intensity in the forest floor (following gap creation) that supported growth and development of seedlings and saplings. Invasion of the forest areas by $B$. papyrifera and $C$. odorata partly contributed to the poor regeneration of this forest. Sapling and seedling diversity decreased with increasing cover of $B$. papyrifera and $C$. odorata until there were no seedlings or saplings of the native species in areas where the invasive species had formed monotypic stands. This is supported by the findings of Sharma and Raghubanshi (2006). B. papyrifera alone constituted $47 \%$ of all the regenerating stems in the DIF, showing their dominance among the regenerating species. The continual dominance of these species may likely affect the regeneration of more native species. The devastating effects of $B$. papyrifera on the regeneration capacity of some native species have also been reported (CSIR, 2002). Seedling diversity was poor in the Nda but the relatively higher numbers of saplings and trees in the smaller diameter class may indicate the ability of the $\mathrm{Nda}$ to recruit more seedlings into the adult phase. This finding is supported by the work of Mishra et al. (2008) and Jyotu Jyotsna and Baidyanath Kumar (2015) in which a higher rate of conversion of saplings to trees was recorded in undisturbed forests.

Table.1 Important Medicinal plants of Nawada

\begin{tabular}{|l|l|l|}
\hline Species & Family & \multicolumn{1}{|c|}{ Habit } \\
\hline Acacia kamerunensis Gand. & Fabaceae & Liana \\
\hline Acanthaceae sp & Acanthaceae & Herb \\
\hline Acacia pentagona (Schum. \& Thonn.) Hooker f & Fabaceae & Liana \\
\hline Afromomum sp & Zingiberaceae & Herb \\
\hline Afzelia bella Harms & Fabaceae & Herb \\
\hline Aidia genipiflora (DC.) Dandy & Rubiaceae & Tree \\
\hline Alafia barteri Oliv & Apocynaceae & Liana \\
\hline Albizia adianthifolia (Schum.) W.F. Wight & Fabaceae & Tree \\
\hline Albizia glaberrima (Schum. \& Thonn.) Benth & Fabaceae & Tree \\
\hline Albizia zygia (DC.) J.F. Macbr & Fabaceae & Tree \\
\hline Alstonia boonei De Wild & Apocynaceae & Tree \\
\hline Amphimas pterocarpoides Harms & Fabaceae & Tree \\
\hline Anchomanes difformis (Blume) Engl. & Araceae & Herb \\
\hline
\end{tabular}




\begin{tabular}{|c|c|c|}
\hline Antiaris toxicaria (Rumph ex Pers.) Leschen & Moraceae & Tree \\
\hline Antrocaryon micraster A. Chev. \& Guillaum & Anacardiaceae & Tree \\
\hline Baphia nitida Lodd. & Fabaceae & Tree \\
\hline Baphia pubescens Hook.f. & Fabaceae & Tree \\
\hline Blighia sapida Kon. & Sapindaceae & Tree \\
\hline Blighia welwitschii (Hiern) Radlk & Sapindaceae & Tree \\
\hline Bombax buonopozense P.Beauv. & Bombacaceae & Tree \\
\hline Bridelia atroviridis Müll.Arg. & Euphorbiaceae & Tree \\
\hline Bridelia grandis Pierre ex Hutch. & Euphorbiaceae & Tree \\
\hline Broussonetia papyrifera Vent. & Moraceae & Tree \\
\hline Bussea occidentalis Hutch. & Fabaceae & Tree \\
\hline Calpocalyx brevibracteatus Harms & Fabaceae & Tree \\
\hline Calycobolus africanus (G.Don) Heine & Convolvulaceae & Tree \\
\hline Calyptrochilum emarginatum Schltr. & Orchidaceae & Epiphyte \\
\hline Ceiba pentandra (L.) Gaertn. & Bombacaceae & Tree \\
\hline Centrocema pubescens Benth. & Fabaceae & Herb \\
\hline Chromolaena odorata (L.) King \& Robinson & Asteraceae & Herb \\
\hline $\begin{array}{l}\text { Chrysophyllum perpulchrum Mildbr. Ex Hutch. \& } \\
\text { Dalziel }\end{array}$ & Sapotaceae & Tree \\
\hline Chrysophyllum sp. & Sapotaceae & Tree \\
\hline Cissus sp. & Vitaceae & Liana \\
\hline Combretum bipindense Engl. \& Diels & Combretaceae & Liana \\
\hline Combretum smeathmannii G.Don & Combretaceae & Liana \\
\hline Combretum sp. & Combretaceae & Liana \\
\hline Cordia millenii Baker & Boraginaceae & Tree \\
\hline Cordia senegalensis Juss. & Boraginaceae & Tree \\
\hline Corynanthe pachyceras K.Schum. & Rubiaceae & Tree \\
\hline Rhaphidophora 814uperb814e N.E.Br. & Araceae & Vine \\
\hline Dalbergia 814uperb814e Benth. & Fabaceae & Liana \\
\hline Diospyros viridicans Hiern & Ebenaceae & Tree \\
\hline Entandrophragma angolense (Welw.) DC. & Meliaceae & Tree \\
\hline Ficus asperifolia Miq. & Moraceae & Shrub \\
\hline Ficus 814uperb814e814814 Vahl & Moraceae & Shrub \\
\hline Ficus sur Forssk. & Moraceae & Tree \\
\hline Ficus tessellataWarb. & Moraceae & Epiphyte \\
\hline Ficus thonningii Blume & Moraceae & Epiphyte \\
\hline Ficus trichopoda Baker & Moraceae & Epiphyte \\
\hline Ficus 814uperb814e814 Vahl & Moraceae & Epiphyte \\
\hline Ficus vogelii Miq. & Moraceae & Epiphyte \\
\hline Funtumia 814uperb814 (Preuss) Stapf & Apocynaceae & Tree \\
\hline Griffonia simplicifolia (Vahl ex DC.) Baill. & Fabaceae & Liana \\
\hline Guarea cedrata (A.Chev.) Pellegr. & Meliaceae & Tree \\
\hline Hippocratea sp. & Celastraceae & Liana \\
\hline Hymenostegia afzelii (Oliv.) Harms & Fabaceae & Tree \\
\hline Khaya anthotheca (Welw.) C.DC. & Meliaceae & Tree \\
\hline Khaya grandifolia C.DC. & Meliaceae & Tree \\
\hline Khaya ivorensis A.Chev. & Meliaceae & Tree \\
\hline Lannea welwitschii (Hiern) Engl. & Anacardiaceae & Tree \\
\hline Lecaniodiscus cupanioides Planch. Ex Benth. & Sapindaceae & Tree \\
\hline
\end{tabular}




\begin{tabular}{|c|c|c|}
\hline Leptoderris sp. & Fabaceae & Liana \\
\hline Lovoa trichilioides Harms & Meliaceae & Tree \\
\hline Macaranga heudelotii Baill. & Euphorbiaceae & Tree \\
\hline Mansonia altissima (A.Chev.) A.Chev. & Sterculiaceae & Tree \\
\hline Marantocloa leucantha (K.Schum.) MilneRedh & Marantaceae & Herb \\
\hline Microdesmis puberula Hook.f. & Pandaceae & Tree \\
\hline Microsorum punctatum (L.) Copel. & Polypodiaceae & Epiphyte \\
\hline Microsorum scolopendria Copel & Polypodiaceae & Epiphyte \\
\hline Milicia 815uperb (Welw.) C.C.Berg. & Moraceae & Tree \\
\hline Millettia chrysophylla Dunn & Fabaceae & Liana \\
\hline Morinda lucida Benth. & Rubiaceae & Tree \\
\hline Morus mesozygia Stapf & Moraceae & Tree \\
\hline Motandra guineensis (Thonn.) A.DC. & Apocynaceae & Liana \\
\hline Myrianthus arboreus P.Beauv. & Cecropiaceae & Tree \\
\hline Olyra latifolia $\mathrm{L}$. & Poaceae & Herb \\
\hline Panicum maximum Jacq. & Poaceae & Grass \\
\hline Parquetina nigrescens (Afzelius) Bullock & Asclepiadaceae & Liana \\
\hline Pennisetum purpureum K.Schum. & Poaceae & Grass \\
\hline Piptadeniastrum africanum (Hook.f.) Brenan & Fabaceae & Tree \\
\hline Pisonia 815uperb815e L. & Nyctaginaceae & Liana \\
\hline Pteris sp. & Pteridaceae & Fern \\
\hline Pycnanthus angolensis (Welw.) Warb. & Myristicaceae & Tree \\
\hline Ricinodendron heudelotii (Baill.) Pierre ex Pax & Euphorbiaceae & Tree \\
\hline Atropa belladonna $\mathrm{L}$. & Solanaceae & Herb \\
\hline Digitalis spp. Linn. & Scrophulariaceae & Herb \\
\hline Rauwolfia serpentine Benth. Ex Kurtz. & Apocyanaceae & Undershrub \\
\hline Catheranthus roseus & Apocyanaceae & Herb \\
\hline $\begin{array}{l}\text { Rinorea oblongifolia (C.H. Wright) Marquand ex } \\
\text { Chipp }\end{array}$ & Violaceae & Tree \\
\hline Salacia elegans Welw. Ex Oliv. & Celastraceae & Liana \\
\hline Salacia owabiensis Hoyle & Celastraceae & Liana \\
\hline Salacia sp. & Celastraceae & Liana \\
\hline Smilax kraussiana Meisn. & Smilacaceae & Liana \\
\hline Sterculia oblonga Mast. & Sterculiaceae & Tree \\
\hline Sterculia rhinopetala K.Schum. & Sterculiaceae & Tree \\
\hline Sterculia tragacantha Lindl. & Sterculiaceae & Tree \\
\hline Terminalia 815uperb Engl. \& Diels & Combretaceae & Tree \\
\hline Trichilia monadelpha (Thonn.) J.J.de Wild & Meliaceae & Tree \\
\hline Trichilia prieureana A.Juss. & Meliaceae & Tree \\
\hline Trilepisium madagascariense DC & Meliaceae & Tree \\
\hline Capsicum sp & Solanaceae & Herb \\
\hline Abutilon indicum & Malvaceae & Shrub \\
\hline Adhatoda vasica & Acanthaceae & Shrub \\
\hline Caesalpinia bonducela & Caesulpinaceae & Tree \\
\hline Cryptostegia grandiflora & Asclepiadaceae & Shrub \\
\hline
\end{tabular}


Table.2 Major plants used as indigenous medicines in Magadh area

\begin{tabular}{|l|l|l|}
\hline Species & Family & Used in Diseases \\
\hline Calotropis gigantica & Asclipiadaceae & Liver, intestine spleen, piles \\
\hline Adhotoda vasica & Acanthaceae & T.B., Cough, Hyperplasia \\
\hline Clitoria ternatia (Aprajita) & Fabaceae & Swelling, Mental headache, Jaundice \\
\hline Achyranthus Aspera & Nyctaginaceae & Appetite, Eyesight \\
\hline Nelumbian speciosum & Nymphaeaceae & Skin diseases, piles \\
\hline Cucumis utilissimus & Cucurbitaceae & Urinary disorder, Gall bladder, cholesterol \\
\hline Nerium odorum & Apocyanaceae & Skin diseases, joint pain \\
\hline Strychros Nuxvomica & Loganiaceae & Nervous system, Joint pain, Dysentery \\
\hline Cucumis melo & Cucurbitaceae & Urinary disorder, kidney pain \\
\hline Daucus Carota & Umbelliferae & Bile, nervous system, Asthma \\
\hline Leucas cephalotus & Lemiaceae & Rheumatism, Cough, Anorexia \\
\hline Calendula officinalis & Asteraceae & Asthma, Cough, tooth, Skin disease \\
\hline Aloe vera & Liliaceae & Liver, spleen, Skin disease \\
\hline Ricinus Communis & Euphorbiaceae & Heart pain, joint pain, piles \\
\hline Mentha spp. & Lemiaceae & Urinary disorder, Worm killer \\
\hline Eclipta alba & Asteraceae & Cough, Skin diseases, Liver, spleen \\
\hline Moringa pterygosperma & Moringaceae & $\begin{array}{l}\text { Anticancer, painkiller, ulcer, cough, liver, spleen, } \\
\text { fever }\end{array}$ \\
\hline Aconitum napellus & Ranunculaceae & Neuralgia and Rheumatism \\
\hline Cassia anguistifolia & Caesalpinaceae & Laxative used in habitual constipation \\
\hline Withania somnifera & Solanaceae & Diuretic, Rheumatism, applied to ulcer carbuncle \\
\hline
\end{tabular}

Fig.1 Composition of medicinal plant species in the various life forms identified in Nawada

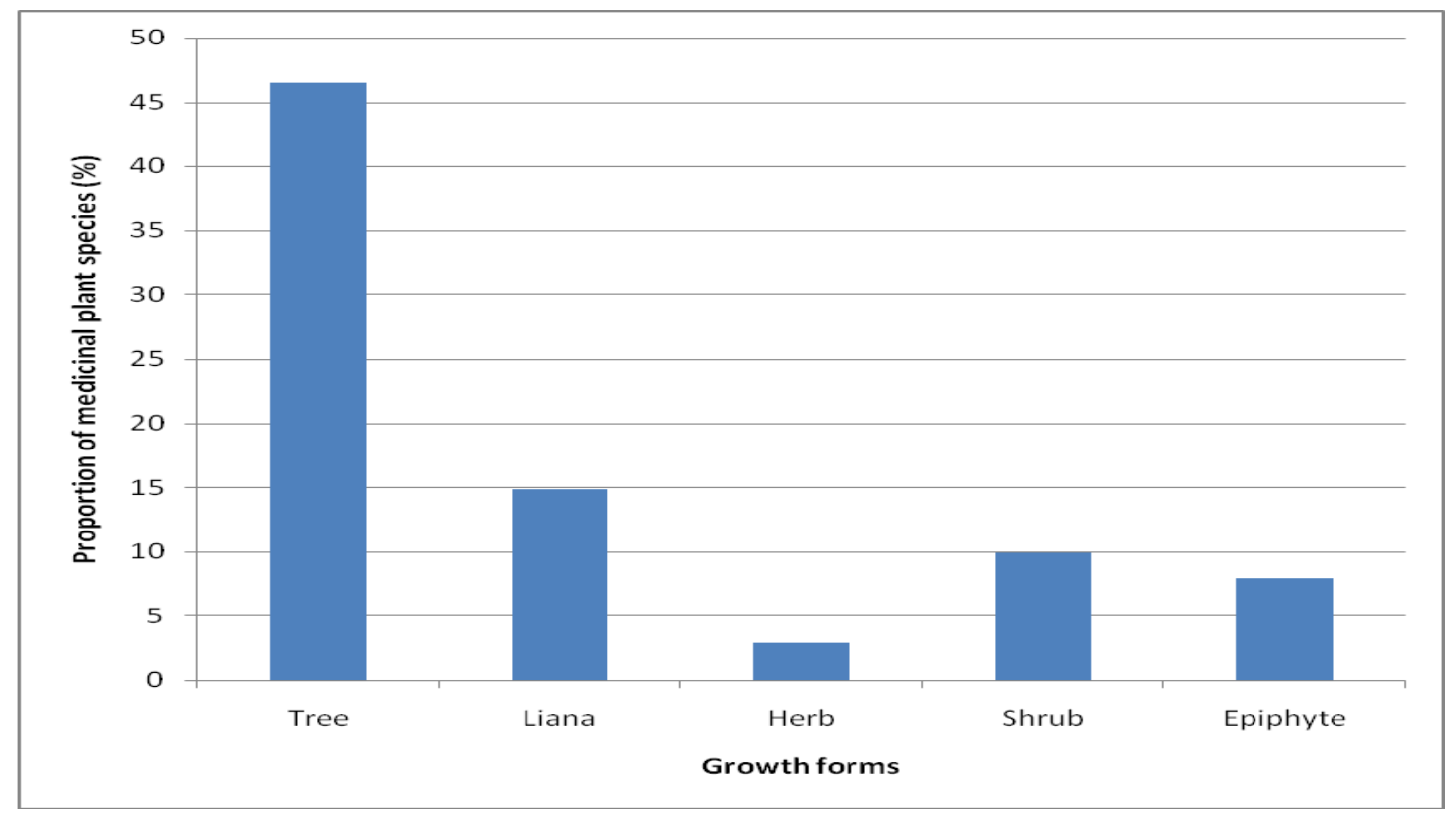


Table.3 Family dominance of medicinal plants

\begin{tabular}{|l|l|}
\hline Family & $\begin{array}{l}\text { Number of } \\
\text { Species }\end{array}$ \\
\hline Fabaceae & 18 \\
\hline Moraceae & 13 \\
\hline Euphorbiaceae & 4 \\
\hline Apocyanaceae & 6 \\
\hline Combretaceae & 4 \\
\hline Sterculariaceae & 4 \\
\hline Meliaceae & 8 \\
\hline Celastraxeae & 4 \\
\hline Poaceae & 3 \\
\hline Bombaceae & 2 \\
\hline Solanaceae & 2 \\
\hline Polypodiaceae & 2 \\
\hline Rubiaceae & 2 \\
\hline Marantaceae & 1 \\
\hline Ppandaceae & 1 \\
\hline Asclepiadaceae & 2 \\
\hline Nyctaginaceae & 1 \\
\hline Ebenaceae & 1 \\
\hline Acanthaceae & 2 \\
\hline Zingiberaceae & 1 \\
\hline Rubiaceae & 2 \\
\hline Araceae & 2 \\
\hline Anacardiaceae & 2 \\
\hline Sapindaceae & 2 \\
\hline Boraginaceae & 2 \\
\hline Cecropiaceae & 1 \\
\hline Bombaceae & 2 \\
\hline Convulvulaceae & 1 \\
\hline Orchidaceae & 1 \\
\hline Asteraceae & 1 \\
\hline Sapotaceae & 2 \\
\hline Vitaceae & 1 \\
\hline Malvaceae & 1 \\
\hline Caesalpinaceae & 2 \\
\hline Asclepiadaceae & 2 \\
\hline
\end{tabular}


Table.4 Abundance and dominance of woody medicinal plant species in all the fourteen blocks of Nawada District

\begin{tabular}{|c|c|c|c|c|c|c|c|c|c|c|c|c|c|c|}
\hline Species & $\mathrm{Nda}$ & $\mathrm{Ap}$ & $\mathrm{Wg}$ & $\mathrm{Pb}$ & Sda & Rjl & $\mathrm{Rh}$ & Kal & $\mathrm{Ha}$ & $\mathrm{Ndg}$ & Nht & GP & $\mathrm{Mkr}$ & $\mathrm{Kac}$ \\
\hline $\begin{array}{l}\text { Acacia } \\
\text { kamerunensis }\end{array}$ & - & - & 0.25 & 0.55 & 0.57 & 0.25 & 0.75 & 1.25 & - & - & - & - & 0.65 & - \\
\hline Acacia pentagon & - & - & 0.35 & 0.35 & 0.65 & 0.26 & 0.55 & 0.15 & 0.25 & 0.65 & - & - & 0.35 & - \\
\hline Acanthaceae sp & 0.67 & 0.75 & - & - & - & - & - & - & 0.55 & - & - & - & 0.65 & - \\
\hline Afromomum sp & - & - & - & - & - & - & - & - & - & - & 0.55 & 0.65 & 0.35 & - \\
\hline Afzelia bella & - & - & - & - & - & 0.57 & - & - & - & - & - & - & 0.65 & - \\
\hline Aidia genipiflora & - & - & - & - & - & 0.58 & - & - & - & - & - & - & 0.45 & - \\
\hline Alafia barteri & - & - & - & - & & 0.55 & - & - & - & - & - & - & 0.65 & - \\
\hline $\begin{array}{l}\text { Albizia } \\
\text { adianthifolia }\end{array}$ & 2.55 & 3.5 & 5.6 & 6.5 & 7.5 & 7.5 & 4.5 & 4.5 & 6.5 & 7.5 & 3.4 & 7.5 & 6.5 & - \\
\hline Albizia zygia & 3.5 & 2.6 & - & - & - & 1.5 & - & - & - & - & - & 0.75 & 6.0 & - \\
\hline Alstonia boonei & - & - & - & - & - & 5.5 & - & - & - & - & - & - & - & - \\
\hline $\begin{array}{l}\text { Amphimas } \\
\text { pterocarpoides }\end{array}$ & - & - & - & 7.5 & - & - & - & - & - & 5.5 & - & - & - & 6.5 \\
\hline $\begin{array}{l}\text { Anchomanes } \\
\text { difformis }\end{array}$ & - & - & - & - & - & - & - & - & - & - & 8.5 & - & - & - \\
\hline $\begin{array}{l}\text { Antiaris } \\
\text { toxicaria }\end{array}$ & 2.5 & - & - & - & - & - & 4.6 & - & - & - & - & - & - & - \\
\hline $\begin{array}{l}\text { Antrocaryon } \\
\text { micraster }\end{array}$ & - & - & 0.5 & - & - & - & 1.5 & - & 3.5 & - & - & - & - & - \\
\hline Baphia nitida & - & - & - & - & - & - & - & - & - & - & - & - & - & - \\
\hline $\begin{array}{l}\text { Baphia } \\
\text { pubescens }\end{array}$ & 0.55 & - & - & - & - & - & - & - & - & 0.25 & - & - & - & - \\
\hline Blighia sapida & 5.5 & - & 4.5 & - & - & - & 6.4 & - & - & - & 5.5 & - & - & - \\
\hline $\begin{array}{l}\text { Blighia } \\
\text { welwitschii }\end{array}$ & - & - & - & 3.6 & - & - & - & - & 4.5 & - & - & - & - & 2.5 \\
\hline $\begin{array}{l}\text { Bombax } \\
\text { buonopozense }\end{array}$ & 7.5 & - & - & - & 8.5 & 9.4 & - & - & - & - & - & - & 6.5 & - \\
\hline $\begin{array}{l}\text { Bridelia } \\
\text { atroviridis }\end{array}$ & - & - & - & - & - & - & - & - & - & - & - & - & 5.5 & - \\
\hline Bridelia grandis & - & - & - & - & - & - & - & - & - & - & - & - & 6.0 & - \\
\hline $\begin{array}{l}\text { Broussonetia } \\
\text { papyrifera }\end{array}$ & - & 2.5 & - & - & - & - & - & 3.5 & - & - & - & 2.6 & - & - \\
\hline $\begin{array}{l}\text { Bussea } \\
\text { occidentalis }\end{array}$ & - & 5.0 & - & - & - & - & - & 3.0 & - & - & - & 2.5 & - & - \\
\hline $\begin{array}{l}\text { Calpocalyx } \\
\text { brevibracteatus }\end{array}$ & - & - & - & 4.5 & - & - & - & - & 3.5 & - & - & - & - & 2.7 \\
\hline $\begin{array}{l}\text { Calycobolus } \\
\text { africanus }\end{array}$ & - & - & - & - & - & - & - & - & 4.6 & - & - & - & - & - \\
\hline $\begin{array}{l}\text { Calyptrochilum } \\
\text { emarginatum }\end{array}$ & - & - & - & - & - & - & - & - & 2.5 & - & - & - & - & - \\
\hline Capsicum sp. & 5.5 & 2.4 & 3.5 & 4.7 & 1.5 & 1.5 & 1.5 & 2.7 & 2.5 & 2.6 & 2.0 & 3.5 & 5.5 & 4.5 \\
\hline Ceiba pentandra & 7.6 & 7.0 & - & - & - & - & 7.0 & - & - & 5.0 & 6.5 & - & 4.5 & 3.6 \\
\hline $\begin{array}{l}\text { Centrocema } \\
\text { pubescens }\end{array}$ & - & - & - & - & - & - & - & - & 5.0 & - & - & - & 6.5 & - \\
\hline
\end{tabular}




\begin{tabular}{|c|c|c|c|c|c|c|c|c|c|c|c|c|c|c|}
\hline $\begin{array}{l}\text { Chromolaena } \\
\text { odorata }\end{array}$ & 4.5 & 4.0 & 3.5 & 2.7 & 3.5 & - & - & - & 5.0 & - & - & - & 6.5 & - \\
\hline $\begin{array}{l}\text { Chrysophyllum } \\
\text { perpulchrum }\end{array}$ & 6.5 & 6.0 & 4.0 & 3.5 & 1.2 & 0.5 & - & 0.6 & - & 0.4 & - & - & - & 0.7 \\
\hline $\begin{array}{l}\text { Chrysophyllum } \\
\text { sp. }\end{array}$ & - & 0.5 & - & 0.7 & - & - & - & 1.5 & - & - & 2.0 & - & - & - \\
\hline Cissus sp. & - & - & - & - & - & - & 2.6 & - & - & - & - & 5.0 & - & - \\
\hline $\begin{array}{l}\text { Combretum } \\
\text { bipindense }\end{array}$ & 4.0 & - & - & 4.7 & 6.5 & - & - & - & - & 3.8 & - & - & - & 2.7 \\
\hline $\begin{array}{l}\text { Combretum } \\
\text { smeathmannii }\end{array}$ & 3.5 & - & - & 3.4 & 4.5 & - & 3.0 & - & - & 4.0 & - & - & - & 3.0 \\
\hline Combretum $s p$ & - & - & - & 3.0 & - & - & - & - & - & - & - & - & - & 2.5 \\
\hline Cordia millenii & - & - & - & - & - & - & - & - & - & - & 4.5 & - & - & - \\
\hline $\begin{array}{l}\text { Cordia } \\
\text { senegalensis }\end{array}$ & - & - & - & - & - & - & - & - & - & - & 5.0 & - & - & - \\
\hline $\begin{array}{l}\text { Corynanthe } \\
\text { pachyceras }\end{array}$ & - & 0.57 & - & - & - & - & - & - & - & - & 0.55 & - & - & - \\
\hline $\begin{array}{l}\text { Rhaphidophora } \\
\text { africana }\end{array}$ & - & 0.7 & - & - & - & - & - & - & - & - & 0.5 & - & - & - \\
\hline $\begin{array}{l}\text { Dalbergia } \\
\text { hostilis }\end{array}$ & 7.5 & 6.5 & 5.0 & 4.7 & 4.6 & 3.5 & 2.8 & 3.6 & 6.5 & 6.5 & 4.5 & 4.5 & 1.0 & 0.5 \\
\hline $\begin{array}{l}\text { Diospyros } \\
\text { viridicans }\end{array}$ & - & - & - & 1.5 & - & - & - & - & - & - & - & - & 1.7 & - \\
\hline $\begin{array}{l}\text { Entandrophragm } \\
\text { a angolense }\end{array}$ & 0.5 & - & - & - & - & - & - & - & - & 0.7 & - & - & - & - \\
\hline Ficus asperifolia & 2.5 & - & - & - & - & 3.6 & - & - & - & - & - & - & 5.5 & - \\
\hline Ficus exasperata & 1.5 & - & - & - & - & 2.4 & - & - & - & - & - & - & 2.0 & - \\
\hline Ficus sur & 2.5 & - & - & 4.5 & - & - & 6.5 & - & - & - & - & 1.5 & - & - \\
\hline Ficus tessellata & 2.5 & - & - & 3.5 & - & - & 5.0 & - & - & - & - & 1.7 & - & - \\
\hline Ficus thonningii & 0.5 & 0.7 & - & 0.5 & - & 0.6 & - & - & - & - & - & - & 0.5 & - \\
\hline Ficus trichopoda & \begin{tabular}{|l|}
0.7 \\
\end{tabular} & 0.4 & - & - & - & 0.5 & - & - & - & - & - & 0.5 & - & 0.7 \\
\hline Ficus umbellata & 2.5 & - & - & - & - & 3.5 & - & - & - & 4.5 & - & - & - & - \\
\hline Ficus vogelii & - & - & - & - & - & - & - & - & \begin{tabular}{|l|}
0.7 \\
\end{tabular} & - & - & - & - & - \\
\hline $\begin{array}{l}\text { Funtumia } \\
\text { elastica }\end{array}$ & - & - & - & - & 1.5 & - & - & - & - & - & - & - & 2.6 & - \\
\hline $\begin{array}{l}\text { Griffonia } \\
\text { simplicifolia }\end{array}$ & - & 3.5 & - & - & - & - & - & 0.5 & - & - & - & - & - & 0.4 \\
\hline Guarea cedrata & - & - & 5.0 & - & - & - & - & - & - & - & 4.5 & - & - & - \\
\hline Hippocratea sp. & - & - & - & 0.3 & - & - & & - & - & - & - & - & - & - \\
\hline $\begin{array}{l}\text { Hymenostegia } \\
\text { afzelii }\end{array}$ & - & - & - & - & - & - & - & - & - & - & - & - & - & 0.5 \\
\hline $\begin{array}{l}\text { Khaya } \\
\text { anthotheca }\end{array}$ & - & - & - & - & - & - & - & - & - & - & - & - & - & 0.4 \\
\hline $\begin{array}{l}\text { Khaya } \\
\text { grandifolia }\end{array}$ & - & - & - & - & - & - & - & - & - & - & - & - & - & 0.5 \\
\hline Khaya ivorensis & - & - & - & - & - & - & - & - & - & - & - & - & - & 0.3 \\
\hline $\begin{array}{l}\text { Lannea } \\
\text { welwitschii }\end{array}$ & - & 0.6 & - & - & - & - & - & - & - & 0.5 & - & - & - & - \\
\hline Lecaniodiscus & - & 0.5 & - & - & - & - & 5.5 & - & - & - & - & - & - & - \\
\hline
\end{tabular}




\begin{tabular}{|c|c|c|c|c|c|c|c|c|c|c|c|c|c|c|}
\hline cupanioides & & & & & & & & & & & & & & \\
\hline Leptoderris sp. & 2.5 & - & - & - & 3.0 & - & - & - & - & - & 3.5 & - & - & - \\
\hline \begin{tabular}{|l|} 
Lovoa \\
trichilioides
\end{tabular} & - & - & 0.7 & 0.5 & - & 0.6 & - & 1.0 & - & - & - & - & 0.5 & - \\
\hline \begin{tabular}{|l|} 
Macaranga \\
heudelotii \\
\end{tabular} & 2.5 & - & - & - & - & - & 3.0 & - & - & - & - & - & - & - \\
\hline \begin{tabular}{|l|} 
Mansonia \\
altissima
\end{tabular} & - & 0.6 & - & - & - & - & - & - & \begin{tabular}{|l|}
0.7 \\
\end{tabular} & - & - & & - & - \\
\hline $\begin{array}{l}\text { Marantocloa } \\
\text { leucantha }\end{array}$ & - & - & 4.0 & - & - & - & - & 5.2 & - & - & - & 3.6 & - & - \\
\hline \begin{tabular}{|l|} 
Microdesmis \\
puberula
\end{tabular} & - & - & - & 0.7 & - & - & - & - & - & 0.5 & - & - & - & 0.4 \\
\hline $\begin{array}{l}\text { Microsorum } \\
\text { punctatum }\end{array}$ & - & - & - & 0.3 & - & - & - & - & - & 0.5 & - & - & - & 0.5 \\
\hline $\begin{array}{l}\text { Microsorum } \\
\text { scolopendria }\end{array}$ & - & - & - & 0.5 & - & - & - & - & - & 0.5 & - & - & - & 0.6 \\
\hline Milicia excelsa & - & - & - & 0.7 & - & - & - & - & - & 0.5 & - & - & - & 0.7 \\
\hline $\begin{array}{l}\text { Millettia } \\
\text { chrysophylla }\end{array}$ & - & 0.5 & - & - & - & - & - & - & 0.7 & - & - & - & - & - \\
\hline Morinda lucida & - & - & - & - & 2.5 & - & - & - & - & - & - & 2.7 & - & - \\
\hline Morus mesozygia & - & - & 2.5 & - & - & - & - & 2.0 & - & - & - & - & - & - \\
\hline $\begin{array}{l}\text { Motandra } \\
\text { guineensis }\end{array}$ & - & - & 2.0 & - & 2.4 & - & - & 1.5 & - & - & - & 1.7 & - & - \\
\hline $\begin{array}{l}\text { Myrianthus } \\
\text { arboreus }\end{array}$ & - & - & 2.6 & - & 2.5 & - & - & 2.0 & - & - & - & 2.5 & - & - \\
\hline Olyra latifolia & - & - & 3.5 & - & - & - & - & - & - & - & - & - & - & - \\
\hline $\begin{array}{l}\text { Panicum } \\
\text { maximum }\end{array}$ & - & 2.7 & - & - & 4.0 & - & - & - & - & 1.8 & - & - & - & - \\
\hline $\begin{array}{l}\text { Parquetina } \\
\text { nigrescens }\end{array}$ & - & - & - & - & - & 0.8 & - & - & - & - & - & - & 0.6 & - \\
\hline $\begin{array}{l}\text { Pennisetum } \\
\text { purpureum }\end{array}$ & - & - & - & - & - & 0.7 & - & - & - & - & - & - & 0.5 & - \\
\hline $\begin{array}{l}\text { Piptadeniastrum } \\
\text { africanum }\end{array}$ & - & - & - & - & - & 0.7 & - & - & - & - & - & - & 0.5 & - \\
\hline Pisonia aculeata & 1.5 & - & - & - & - & - & - & 1.7 & - & - & - & - & - & - \\
\hline Pteris sp. & 6.5 & 5.0 & 6.5 & 6.0 & 4.0 & 2.5 & 4.0 & 2.5 & 3.5 & 3.0 & 2.7 & 2.0 & 3.5 & 1.5 \\
\hline $\begin{array}{l}\text { Pycnanthus } \\
\text { angolensis }\end{array}$ & 3.5 & - & - & - & 5.0 & - & - & - & - & - & - & 2.5 & - & - \\
\hline $\begin{array}{l}\text { Ricinodendron } \\
\text { heudelotii }\end{array}$ & 1.5 & - & - & 0.7 & - & - & - & - & 0.5 & - & - & - & 0.5 & - \\
\hline $\begin{array}{l}\text { Atropa } \\
\text { belladonna }\end{array}$ & 3.2 & - & - & 3.5 & - & - & 4.0 & - & - & - & - & 3.5 & - & - \\
\hline Digitalis spp & - & 4.0 & 3.5 & - & - & 7.0 & - & - & 6.0 & - & - & - & 5.0 & - \\
\hline $\begin{array}{l}\text { Rauwolfia } \\
\text { serpentine }\end{array}$ & - & & - & - & 5.5 & - & - & - & - & - & 6.5 & - & - & 6.0 \\
\hline $\begin{array}{l}\text { Catheranthus } \\
\text { roseus }\end{array}$ & 2.5 & 2.0 & 1.0 & 1.5 & 2.7 & 3.5 & 3.7 & 4.5 & 3.7 & 3.5 & 3.0 & 2.5 & 2.0 & 3.6 \\
\hline $\begin{array}{l}\text { Rinorea } \\
\text { oblongifolia }\end{array}$ & 0.5 & - & - & - & 0.6 & - & - & - & 0.5 & - & - & 0.4 & - & - \\
\hline
\end{tabular}




\begin{tabular}{|c|c|c|c|c|c|c|c|c|c|c|c|c|c|c|}
\hline Salacia elegans & 1.4 & - & - & 1.5 & - & - & - & - & - & - & 1.4 & - & - & - \\
\hline $\begin{array}{l}\text { Salacia } \\
\text { owabiensis }\end{array}$ & $\begin{array}{l}1 . \\
6\end{array}$ & - & - & 1.7 & - & - & 2.5 & - & - & - & 2.0 & - & - & - \\
\hline Salacia sp. & \begin{tabular}{|l|}
1.5 \\
\end{tabular} & - & - & 2.0 & - & - & 3.0 & - & - & - & 1.7 & - & - & - \\
\hline $\begin{array}{l}\text { Smilax } \\
\text { kraussiana }\end{array}$ & \begin{tabular}{|l|}
1.7 \\
\end{tabular} & - & - & 2.5 & - & - & 3.0 & - & - & - & 4.7 & - & - & - \\
\hline $\begin{array}{l}\text { Sterculia } \\
\text { oblonga }\end{array}$ & 3.6 & - & 3.5 & - & 2.7 & - & - & 2.5 & - & 3.0 & - & - & - & 4.0 \\
\hline $\begin{array}{l}\text { Sterculia } \\
\text { rhinopetala }\end{array}$ & 2.3 & - & 3.6 & - & 2.5 & - & - & - & - & - & - & - & - & - \\
\hline $\begin{array}{l}\text { Sterculia } \\
\text { tragacantha }\end{array}$ & - & - & - & - & 4.5 & - & - & - & - & - & - & - & - & 2.7 \\
\hline $\begin{array}{l}\text { Terminalia } \\
\text { superba }\end{array}$ & 1.5 & 3.5 & - & 5.0 & - & - & - & - & - & - & - & 1.4 & - & - \\
\hline $\begin{array}{l}\text { Trichilia } \\
\text { monadelpha }\end{array}$ & - & - & - & - & - & 0.5 & - & - & - & - & 0.7 & - & - & - \\
\hline $\begin{array}{l}\text { Trichilia } \\
\text { prieureana }\end{array}$ & - & - & - & - & - & 1.5 & - & - & - & - & 2.0 & - & - & - \\
\hline $\begin{array}{l}\text { Trilepisium } \\
\text { madagascariense }\end{array}$ & - & - & - & - & - & 2.0 & - & - & - & - & 1.7 & - & - & - \\
\hline Abutilon indicum & & 1.3 & & & & & 0.5 & & & & & 1.5 & 0.5 & \\
\hline Adhatoda vasica & & 1.5 & & & & & 1.6 & & & & & 1.8 & 1.6 & \\
\hline $\begin{array}{l}\text { Caesalpinia } \\
\text { bonducela }\end{array}$ & 1.7 & & 2.5 & & 2.6 & & 1.4 & 1.6 & & 1.5 & 0.5 & & 0.5 & \\
\hline $\begin{array}{l}\text { Cryptostegia } \\
\text { grandiflora }\end{array}$ & & & & 2.0 & & 2.5 & & & & & 1.7 & 1.6 & 2.0 & 1.4 \\
\hline
\end{tabular}

Fig.2 Family dominance of medicinal plant species in Nawada District

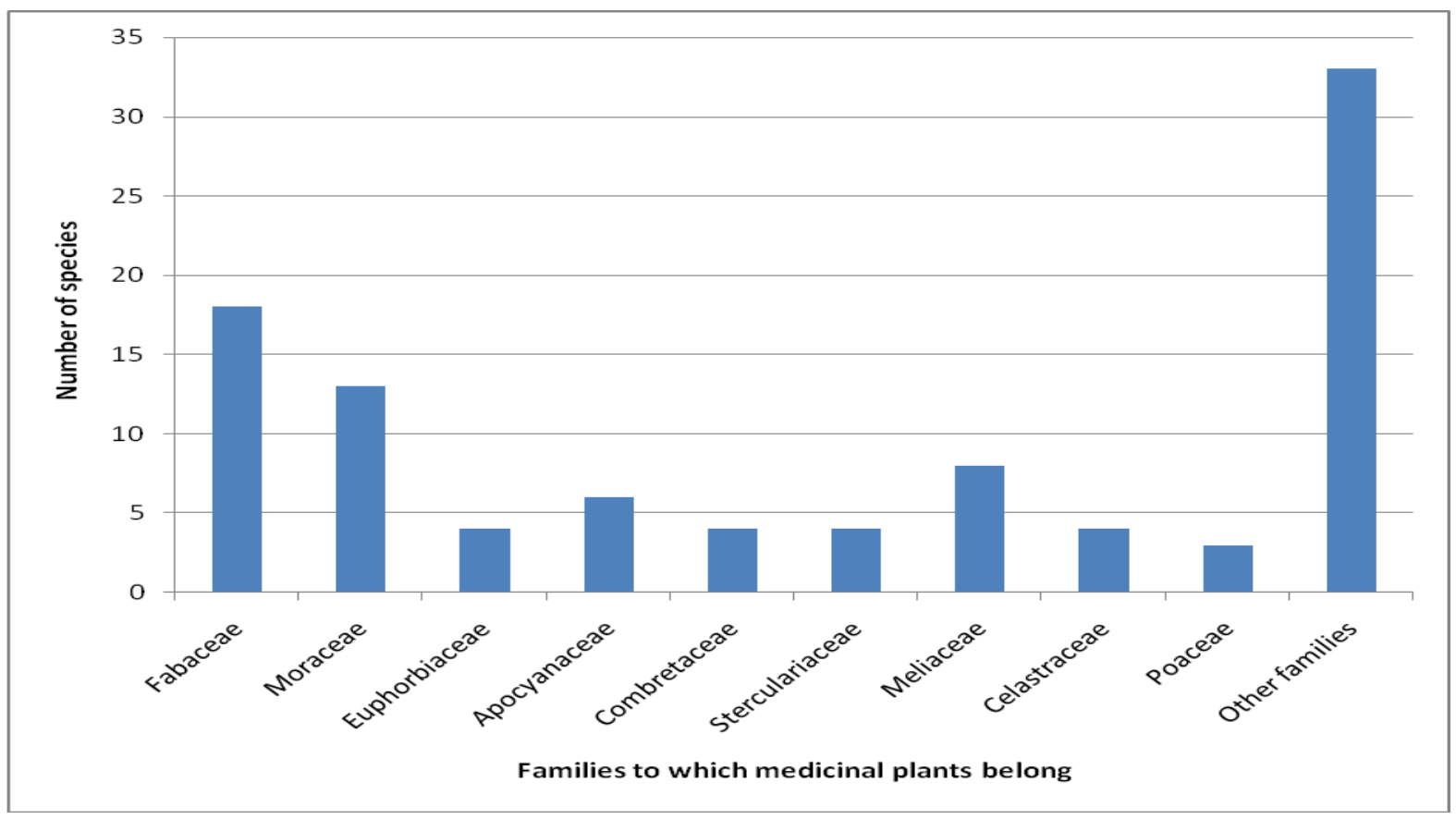




\section{Int.J.Curr.Microbiol.App.Sci (2016) 5(6): 806-826}

Table.5 Summary characteristics of the Floristic composition and structure of the medicinal plants in fourteen blocks of Nawada

\begin{tabular}{|c|c|c|c|c|c|c|c|c|c|c|c|c|c|c|}
\hline $\begin{array}{l}\text { Characteristi } \\
\text { cs }\end{array}$ & $\mathrm{Nda}$ & Ap & $\mathrm{Wg}$ & $\mathrm{Pb}$ & Sda & Rjl & $\mathrm{Rh}$ & Kal & $\mathrm{Ha}$ & Ndg & Nht & Gp & $\mathrm{Mkr}$ & $\mathrm{Kac}$ \\
\hline $\begin{array}{l}\text { Number of } \\
\text { tree } \\
\text { individuals } \\
\text { (density/ha) }\end{array}$ & 85 & 95 & 107 & 154 & 250 & 214 & 215 & 150 & 280 & 230 & 107 & 114 & 217 & 285 \\
\hline $\begin{array}{l}\text { Number of } \\
\text { individual } \\
\text { shrubs } \\
\text { (density/ha) }\end{array}$ & 8 & 12 & 10 & 13 & 15 & 18 & 16 & 17 & 10 & 14 & 17 & 13 & 9 & 11 \\
\hline $\begin{array}{l}\text { Density of } \\
\text { Liana/ha }\end{array}$ & 121 & 105 & 108 & 126 & 124 & 60 & 58 & 69 & 52 & 104 & 85 & 108 & 75 & 85 \\
\hline $\begin{array}{l}\text { Shannon- } \\
\text { Wienner } \\
\text { Index }\end{array}$ & 2.5 & 2.6 & 2.9 & 3.5 & 3.4 & 3.6 & 2.8 & 3.5 & 3.7 & 2.8 & 2.9 & 3.1 & 3.6 & 3.4 \\
\hline $\begin{array}{l}\text { Shannon- } \\
\text { Wienner } \\
\text { Index for } \\
\text { sampling }\end{array}$ & 1.30 & 1.34 & 1.35 & 2.70 & 2.50 & 1.45 & 2.50 & 1.36 & 1.35 & 1.34 & 2.68 & 2.36 & 1.85 & 1.80 \\
\hline $\begin{array}{l}\text { Mean canopy } \\
\text { height }(\mathrm{m})\end{array}$ & $35.5 \pm 3.5$ & $36.6 \pm 3.2$ & $29.8 \pm 3.4$ & $32.5 \pm 2.5$ & $34.40 \pm 2.6$ & $28.30 \pm 1.58$ & $\begin{array}{l}27.5 \\
0 \pm 1 \\
75\end{array}$ & $\begin{array}{l}26.35 \pm \\
2.50\end{array}$ & $\begin{array}{l}27.25 \pm \\
3.12\end{array}$ & $\begin{array}{l}32.15 \\
\pm 1.78\end{array}$ & $\begin{array}{l}30.26 \pm 2.1 \\
5\end{array}$ & $\begin{array}{l}29.10 \pm \\
2.16\end{array}$ & $\begin{array}{l}27.35 \pm \\
1.85\end{array}$ & $\begin{array}{l}35.15 \pm \\
1.26\end{array}$ \\
\hline $\begin{array}{l}\text { Mean canopy } \\
\text { cover }(\%)\end{array}$ & $54.3 \pm 4.5$ & $60.5 \pm 2.5$ & $61.5 \pm 2.6$ & $64.5 \pm 2.4$ & $71.2 \pm 4.2$ & $81.3 \pm 4.3$ & $\begin{array}{l}78.5 \\
\pm 3.5\end{array}$ & $\begin{array}{l}76.6 \pm 3 . \\
5\end{array}$ & $72.5 \pm 1.5$ & $\begin{array}{l}68.5 \pm \\
5.0\end{array}$ & $56.2 \pm 2.6$ & $\begin{array}{l}58.5 \pm 3 . \\
6\end{array}$ & $\begin{array}{l}59.5 \pm 4 \\
.5\end{array}$ & $\begin{array}{l}80.5 \pm \\
3.4\end{array}$ \\
\hline $\begin{array}{l}\text { Mean basal } \\
\text { area }\left(\mathrm{m}^{2} / \mathrm{ha}\right)\end{array}$ & $52.5 \pm 3.2$ & $35.5 \pm 0.8$ & $32.6 \pm 0.8$ & $45.2 \pm 1.2$ & $43.5 \pm 3.2$ & $55.6 \pm 3.5$ & $\begin{array}{l}60.4 \\
\pm 2.6 \\
\end{array}$ & $\begin{array}{l}58.5 \pm 0 . \\
8 \\
\end{array}$ & $53.5 \pm 2.5$ & $\begin{array}{l}54.5 \pm \\
4.5 \\
\end{array}$ & $38.6 \pm 3.2$ & $\begin{array}{l}37.5 \pm 0 . \\
9\end{array}$ & $\begin{array}{l}63.5 \pm 2 \\
.5\end{array}$ & $\begin{array}{l}64.7 \pm 2 . \\
6\end{array}$ \\
\hline
\end{tabular}


In conclusion, human disturbances have influenced the biodiversity, floristic composition of the district Nawada to some extent. Invasion on the other hand did not have much effect on floristic composition of the Nawada due to the early stage of invasion. Thus, proper management intervention is required to mitigate the impact of $B$. papyrifera and $C$. odorata before it gets out of control. Logging affected the structural complexity of the forest reserve through the removal of large and tall trees as well as gap creation. The forest regions of Nawada (Magadh area) had better capacity of recruiting saplings into the adult stage. Invasion of the DIF by $B$. papyrifera and $C$. odorata affected regeneration of native species. The forest reserve of Magadh looks floristically rich and structurally complex in the face of logging, farming activities and invasion in some parts of the forest. Thus, there is the need to curb the anthropogenic activities and plant invasion so as to protect the integrity of the forest including medicinal plants.

\section{Acknowledgements}

The first author is grateful to Dr. Baidyanath Kumar, Visiting Professor, Department of Biotechnology, Patna Science College, Patna for providing necessary suggestion and for helping in identification of plant species.

\section{References}

Addo-Fordjour P, Anning AK, Addo MG, Osei MF (in press). Composition and distribution of vascular epiphytes in a tropical semideciduous forest, Ghana. Afr. J. Ecol.

Addo-Fordjour P, Anning AK, Atakora EA, Agyei PS (2008). Diversity and distribution of climbing plants in a semi-deciduous rain forest, KNUST
Botanic Garden, Ghana. Int. J. Bot. 4: 186-195.

Addo-Fordjour P, Anning AK, Larbi JA, Akyeampong S (2009). Liana species richness, abundance and relationship with trees in the Bobiri forest reserve, Ghana: impact of management systems. For. Ecol.

Manage. 257:1822-1828.

Ambika SR (1996). Ecological adaptations of Chromolaena odorata (L.) King \& Robinson. In: Proceedings of the Fourth International Workshop on Biological Control and Management of Chromolaena odorata, Bangalore, India, pp. 1-10.

Anning AK, Akyeampong S, Addo-Fordjour $\mathrm{P}$, Anti KK, Kwarteng A, Tettey YF (2008). Floristic composition and vegetation structure of the KNUST Botanic Garden, Kumasi, Ghana. JUST 28: 103-116.

Arbonnier M (2004). Trees, shrubs and lianas of West African dry zones. CIRAD, MARGRAF Publishers.

Blanc L, Maury-Lechon G, Pascal J-P (2000). Structure, floristic composition and natural regeneration in the forests of Cat Tien

National Park, Vietnam: an analysis of the successional trends. J. Biogeogr. 27: 141-157.

Busing RT (1995). Disturbance and the population dynamics of Liriodendron tulipifera: simulations with a spatial model of forest

Campbell DG, Douglas CD, Prance GT, Maciel UN (1986). Quantitative ecological inventory of terra firme and varzea tropical forest on the Rio Xingu, Brazilian Amazon. Brittonia 38: 369-393.

Ceccon E, Omstead I, Vázquez-Yanes C, Campo-Alves J (2002). Vegetation and soil properties in two tropical dry forests of differing regeneration status 
in Yucatán. Agrociencia 36: 621-631. Cragg, G. M DJ Newman, KM Snader: Gen Pharmacol 1996, 27(4): 713-22

CSIR (2002). Country Report on Invasive Alien Species in Ghana: Removing Barriers to Invasive Plant Management in Africa. Council for Sci. and Ind. Res., Accra, Ghana, pp 49-57.

Doyle TW (1981). The role of disturbance in the gap dy-namics of a montane rain forest: an application of a tropical forest succession model. In West DC, Shugart HH, Botkin DB (eds) Forest succession: concepts and application. Springer-Verlag, Berlin, Germany, pp. 56- 73.

Epp GA (1987). The seed bank of Eupatorium odoratum along a successional gradient in a tropical rain forest in Ghana. J. Trop. Ecol. 3: 139149.

Gharpure, Y. H. Chemical News, June 2011, 22

Gimaret-Carpentier C, Pelissier R, Pascal J$\mathrm{P}$, Houillier F (1998). Sampling tree species diversity in a dense moist evergreen forest

with regard to its structural heterogeneity. J. Veg. Sci. 9: 161-172.

Hall JB and Swaine MD (1988). Distribution and ecology of vascular plants in a tropical rain forest. Dr W. Junk Publishers, The Hague. succession. J. Ecol. 83:45-53.

Haslam, E. Nat Drod Rep 2003 Feb; 20(1): $79-110$

Haugaasen T, Barlow J, Peres CA (2003). Surface wildfires in central Amazonia: Short-term impact on forest structure and carbon loss. For. Ecol. Manage. 179: 321-331.

Haugaasen T, Peres CA (2006). Floristic, edaphic and structural characteristics of flooded and unflooded forests in the lower Rio
Purús region of central Amazonia, Brazil. Acta Amazon. 36: 25-36.

Hawthorne WD (1990). Field guide to the forest trees of Ghana. Chatham: Natural Resources Institute, for the Overseas Development Aministration, London. Ghana Forestry Series 1.

Hawthorne WD (1993). Forest regeneration after logging: findings of a study in the Bia South Game Production Reserve, Ghana. ODA Forestry Series. Natural Resources Institute, Chatham.

Hawthorne WD (1994). Fire damage and forest regeneration in Ghana. ODA Forestry Series. Natural Resources Institute, Chatham.

Hawthorne WD, Jongkind C (2006). Woody plants of western African forests: a guide to the forest trees, shrubs and lianes from Senegal to Ghana. Royal Botanic Gardens, Kew, UK.

Hill JL, Curran PJ (2003). Area, shape and isolation of tropical forest fragments: effects on tree species diversity and implications for

conservation forest area. J. Biogeogr. 30: 1391-1403.

Jyoti Jyotsna and Baidyanath Kumar (2015): Biodiversity and Floristic composition of medicinal plants of Darbhanga, Bihar, India. International Journal of Current Microbiology and Applied Science, 4 (12), 263-283

Klinge H, Adis J and Worbes M (1995). The vegetation of a seasonal várzea in the lower Solimões river, Brazilian Amazon. Acta

Amazonica 25: 201-220.

Laidlaw M, Kitching R, Goodall K, Small A, Stork N (2007). Temporal and spatial variation in an Australian tropical rainforest. Austral Ecol. 32: 10-20.

Lambert FR, Marshall AG (1991). Keystone characteristics of birddispersed Ficus in a Malaysian Lowland Rain Forest. 
J. Ecol. 79:793- 809.

Lieberman D, Lieberman M (1984). The causes and consequences of synchronous flushing in a dry tropical forest. Biotropica 16: 193-201.

Madoffe S, Hertel GD, Rodgers P, O'Connell B, Killenga R (2006). Monitoring the health of selected eastern arc forests in Tanzania. Afr. J. Ecol. 44: 171-177.

Mishra RK, Upadhyay VP, Mohanty RC (2008). Vegetation ecology of the Similipal Biosphere Reserve, Orissa, India. Appl. Ecol. Env. Res. 6: 89-99.

Odoom FK (2005). Chainsawing in the Natural Forests of Ghana: An assessment of the socio-economic impacts of this practice, Forest Harvesting Case-Study 21 Food and Agriculture Organization of the United Nations, Rome.

Opoku K (2006). Forest governance in Ghana: An NGO perspective. A report produced by Forest Watch Ghana for FERN. Zuidam Uithof, Utrecht, Netherlands.

Parker IM, Simberloff D, Lonsdale WM, Goodell K, Wonham M (1999). Impact: toward a framework for understanding the ecological effects of invaders. Biol. Invasions 1: 3-19.

Parthasarathy N (2001). Changes in forest composition and structure in three sites of tropical evergreen forest around Sengaltheri, Western Ghats. Curr. Sci., 80: 389-393.

Poorter L, Bongers F, Kouamé FN, Hawthorne WD (Eds) (2004). Biodiversity of West African forests: an ecological atlas of woody plant species. CABI publishers.

Richardson DM, Pyešk $\mathrm{P}$, Rejmánek $\mathrm{M}$, Barbour MG, Panetta FD, West CJ (2000). Naturalization and invasion of alien plants: concepts and definitions. Divers. Distrib. 6: 93-107.
Ravi kumar et. al., Indian J Exp Biol 2011, 49, 455

Riswan S (1987). Structure and floristic composition of a mixed dipterocarp forest at Lempake, East Kalimantan. In: Kostermans,

A.G.J.H. (Ed.), Proceedings of the Third Round Table Conference on Dipterocarps (16-20 April 1985, Mulawarman University, Samarinda, East Kalimantan, Indonesia), pp 435457.

Ryan MG, Yoder BJ (1997). Hydraulic Limits to Tree Height and Tree Growth. Bio. Sci., 47: 235-242.

Sala OE, Chapin FS, Armesto JJ, Berlow E, Bloomfield J (2000). Global biodiversity scenarios for the year 2100. Sci. 287: 1770-1774.

Senbeta F, Schmitt C, Denich M, Demissew $\mathrm{S}$, Vlek PLG, Preisinger $\mathrm{H}$, Woldemariam T, Teketay D (2005). The diversity and distribution of lianas in the Afromontane rain forests of Ethiopia. Divers. Distrib. 11: 443-452.

Sharma GP, Raghubanshi AS (2006). Tree population structure, regeneration and expected future composition at different levels of

Lantana camara L. invasion in the Vindhyan tropical dry deciduous forest of India. Lyonia 11: 27-39.

Ssegawa P, Nkuutu DN (2006). Diversity of vascular plants on Ssese Islands in Lake Victoria, Central Uganda. Afr. J. Ecol. 44: 22-29.

Stein B, Kutner LS, Adams JS (2000). Precious Heritage: The Status of Biodiversity in the United States. Oxford: Oxford University Press, pp 399.

Swaine MD, Hawthorne WD, Bongers F, Toledo Aceves M (2005). Climbing plants in Ghanaian forests. In: Bongers F, Parren MPE, Traore' D (Eds) Forest climbing plants of West Africa: 
diversity, ecology and management. CAB International, Wallingford,

Oxfordshire, UK, pp. 93-108.

Taylor CJ (1960). Synecology and silverculture in Ghana. Thomas Nelson and Sons, London, UK.

Terborgh J (1992). Maintenance of diversity in tropical forests. Biotropica 24: $253-$ 292.

Tilman D (1982). Resource Competition and Community Structure. Princeton University Press, NJ.

Tilman D (1988). Plant strategies and the dynamics and structure of plant communities. Princeton University Press. Princeton, NewJersey.
Vorddzobe VV, Attuquayefio DK, Gbogbo F (2005). The flora and mammals of the moist semi-deciduous forest zone in the Sefwi-

Wiawso District of the Western Region, Ghana. W. Afr. J. Appl. Ecol. 8: 4964.

Wittmann F, Junk WJ (2003). Sapling communities in Amazonian whitewater forests. J. Biogeogr. 30: 1533-1544.

WCMC (1992). World Conservation Monitoring Centre. Global Biodiversity: Status of Earth's Living Resources. Chapman and Hall, London, UK.

\section{How to cite this article:}

Ateeque Ahmad, S. M., Baidyanath Kumar and Nandji Kumar. 2016. Floristic composition of medicinal plants of Nawada District, Bihar, India. Int.J.Curr.Microbiol.App.Sci. 5(6): 806-826. doi: http://dx.doi.org/10.20546/ijcmas.2016.506.089 